expectations of them. Our results show that trainees on these schemes were more likely to complete a post in obstetrics and gynaecology or paediatrics, though little educational advantage seems to have been gained as they did not receive more teaching and had similar difficulties obtaining study leave as trainees on self constructed schemes. Surprisingly, they were also less likely to consider the teaching they did receive as being orientated towards general practice, although this may be because their expectations were higher. This is a sad state of affairs. Formal vocational training schemes were developed to provide an integrated training programme of hospital and general practice posts. It seems that in the North Western region they fall well short of this. Is this also true for the rest of the UK?

In two important recent reports ${ }^{12}{ }^{13}$ the general issue of basic specialist training has been explored. Among the recommendations are that trainees need to participate regularly in organised educational activities; that each trainee should have a named educational supervisor responsible for both teaching and providing unambiguous feedback; and that training opportunities should be available to consultants and senior registrars to help develop their skills as teachers. In many ways these recommendations mirror what has happened in the general practice component of vocational training over the past decade.

We would add three further suggestions which have particular relevance to the North Western region. Firstly, priority should be given to the task of agreeing educational objectives for the hospital period of vocational training. ${ }^{15} 16$ Secondly, protected study leave should be organised during this period to allow educational input that is directly orientated towards general practice. Finally, trainees on a formal scheme should spend some time at the beginning of the scheme in an approved training practice, thus enabling them to direct their learning more appropriately during subsequent hospital posts.
We are encouraged because since this study was undertaken noticeable progress has been made in the North Western region towards implementing some of these recommendations. It is our hope that the publication of this paper will be a catalyst for further discussion and change.

We thank the North West England Faculty of the Royal College of General Practitioners for providing administrative support and funds for this study. We also thank the Regional Adviser in General Practice, and local course organisers for their cooperation.

1 Gray DJP. The history of vocational training. In: Training for general practice. Plymouth: MacDonald and Evans, 1982:1-17.

2 National Health Services Act. Sections 31,32. London: HMSO, 1977.

3 Joint Committee on Postgraduate Training for General Practice. Selection of posts in hospital and community medicine for vocational training in general practice. London: JCPTGP, 1980.

4 Ronalds C, Douglas A, Gray DJP, Selley O, eds. Fourth national trainee conference. London: Royal College of General Practitioners, 1981. (Occasional Paper 18.

5 Huson A, Cole F. A survey of general practice training in the North West region. Trainee 1982;2:46-53.

6 Cyna AM, Przyslo FR. Are the recommendations being met in the general practice year of vocational training? Trainees' views in the West Midlands Region. BrMed J 1987;294:416-8.

7 Carne S, ed. What others do: is vocational training for general practice working? Modern Medicine 1986; June:59-60.

8 Firth-Cozens J. Emotional distress in junior house officers. $\mathrm{Br}$ Med $\mathrm{f}$ 1987;295:533-6.

9 Kiff RS, Sykes PA. Who undertakes the consultation in the outpatients department? BrMed F 1988;296:1511-2.

10 Orton DI, Gruzelier JH. Adverse changes in mood and cognitive performance of house officers after night duty. Br Med f 1989;298:21-3.

11 Review Body on Doctors' and Dentists' Remuneration. Seventeenth report. London: HMSO, 1987.

12 General Medical Council: Education Committee. Recommendations on the training of specialists. London: GMC, 1987.

13 Council for Postgraduate Medical Education in England and Wales. The problems of the senior house officer. London: CPME, 1987.

14 Styles WMCN. Swan song of the CPME in England and Wales. $f$ R Coll Gen Pract 1988;38:389-90.

15 Tait I. Agreed educational objectives for the hospital period of vocational training. Fournal of the Association of Course Organisers 1987;2:179-82.

16 Oxford Region Course Organisers and Regional Advisers Group. Priority objectives for general practice vocational training. London: Royal College of General Practitioners, 1985. (Occasional Paper 30.)

(Accepted 17 February 1989)

\section{Nottingham University Medical School, Nottingham NG7 2UH Leon Polnay, FRCP, senior lecturer in child health Mike Pringle, MD, senior lecturer, department of general practice}

Correspondence to: $\mathrm{Dr}$ Polnay.

\title{
General practitioner training in paediatrics in the Trent region
}

\author{
Leon Polnay, Mike Pringle
}

\begin{abstract}
A total of 259 postal questionnaires were sent to all final year vocational trainees and new principals in general practice in the Trent region to find out how much training in paediatrics they had had. Questionnaires were returned by 105 trainees and 139 principals $(244 ; 94 \%)$. Overall $72 \%(175)$ had taken up a hospital post in paediatrics during training, but among the 138 doctors who were on or had completed a three year vocational training scheme the proportion was slightly higher $(82 \% ; 115)(p=0.01)$. Among the 175 who had had a post in paediatrics 108 $(62 \%)$ had been given teaching sessions every week, and for half of these doctors the sessions lasted over one hour a week.

Seventy five $(54 \%)$ of the 139 principals reported that in their training in a general practice they had received no teaching about child health and a fifth said that they had not attended a clinic for children; $47(34 \%)$ had received no training on procedures for dealing with cases of child abuse. The doctors who had held posts as senior house officers in paediatrics were more likely to report that they had adequate skills in paediatrics than those who had not, but overall only $62(44 \%)$ reported that they could run a preschool child health surveillance programme.
\end{abstract}

Extra paediatric posts in hospital are needed, but in the mean time improvements can be made to the teaching content in hospital and in the general practice attachment and postgraduate training in paediatrics provided for all general practitioners.

\section{Introduction}

It has been suggested that general practitioners should be more widely concerned in child health surveillance. In 1976 the Court report recommended the development of a specialist general practitioner paediatrician. ${ }^{1}$ In 1982 the Royal College of General Practitioners encouraged general practitioners to take a greater role in child health. ${ }^{2}$ Most recently the government's white paper has sought to expand the role of general practitioners in community health.

Because of the recommendations in these reports the paediatric training that general practitioners now receive needs to be reviewed. Figures from the Royal College of General Practitioners show that of the first 3916 applicants who registered with the college after completing postgraduate training in general practice only $1645(42 \%)$ had included a hospital post in paediatrics in their training scheme. The relevance to general practice of training in paediatrics in hospital 
must be questioned, however, and clearly depends on the teaching content of the post.

We decided to collect information on the career experience and training in paediatrics of aspiring and recent entrants to general practice in the Trent region.

\section{Methods}

Two groups of doctors were identified-trainees who were in the last part of vocational training in a general practice $(n=108)$ and general practitioner principals in their first year of practice $(n=151)$. The names of the trainees were obtained from the course organisers of the 10 vocational training schemes in the Trent region and included those who constructed their own schemes. The names of the new principals were supplied by the eight family practitioner committees in the region. Some of these doctors had completed training some time before or were changing practices.

The doctors were sent a questionnaire concerning their hospital experience in paediatrics. Only the new principals were asked about the content of their training for general practice since only they could comment on its entire content. They were also asked to assess their paediatric skills to evaluate the whole training experience.

Non-respondents were sent a follow up letter. Altogether, 105 trainees (97\%) and 139 new principals $(92 \%)$ responded, giving an overall response rate of $\mathbf{9 4 \%}$ (table I).

\section{Results}

Table I shows details of age, sex, and training of the respondents. A total of $175(71 \%)$ aspiring or recent entrants into general practice had had a senior house officer post in paediatrics, and this was more likely among those on three year vocational training schemes

TABLE I-Age and sex of respondents, whether they were in or had completed a three year training scheme, and whether training included a six month paediatrics post in hospital

\begin{tabular}{|c|c|c|c|}
\hline & \multicolumn{3}{|c|}{ Respondents } \\
\hline & $\begin{array}{c}\text { Final year } \\
\text { vocational trainees }\end{array}$ & $\begin{array}{c}\text { First year } \\
\text { principals in general } \\
\text { practice }\end{array}$ & All \\
\hline Total No of questionnaires sent & 108 & 151 & 259 \\
\hline No $(\%)$ of questionnaires returned & $105(97)$ & $139(92)$ & $244(94)$ \\
\hline Mean age of respondents (years) & 28.6 & $31 \cdot 4$ & $30 \cdot 2$ \\
\hline Male:female & $1.5: 1$ & $1 \cdot 3: 1$ & $1 \cdot 4: 1$ \\
\hline $\begin{array}{l}\text { No (\%) who were in or had completed a three } \\
\text { year training scheme }\end{array}$ & $63(60)$ & $75(53)$ & $138(56)$ \\
\hline $\begin{array}{l}\text { No }(\%) \text { whose training included six month } \\
\text { paediatric post in hospital }\end{array}$ & $76(72)$ & $99(71)$ & $175(71)$ \\
\hline
\end{tabular}

TABLE II - Reported experience of doctors who had included a senior house officer post in paediatrics in their training. Figures are numbers (percentages)

\begin{tabular}{|c|c|c|c|}
\hline & \multicolumn{3}{|c|}{ Respondents } \\
\hline & $\begin{array}{c}\text { Final year } \\
\text { vocational trainees } \\
(n=76)\end{array}$ & $\begin{array}{c}\text { First year } \\
\text { principals in general } \\
\text { practice }(n=99)\end{array}$ & $\underset{(n=175)}{\text { All }}$ \\
\hline \multirow{2}{*}{\multicolumn{4}{|c|}{$\begin{array}{l}\text { Thought a three month hospital paediatric job } \\
\text { would be adequate } \\
\text { Had regular teaching sessions as a senior house } \\
\text { officer of: }\end{array}$}} \\
\hline & & & \\
\hline Under 1 hour & $28(37)$ & $23(23)$ & $51(29)$ \\
\hline $1-2$ Hours & $30(39)$ & $58(59)$ & $88(50)$ \\
\hline Over 2 hours & $4(5)$ & & $4(2)$ \\
\hline Total & $62(81)$ & $81(81)$ & $143(81)$ \\
\hline Had regular teaching sessions at least once a week & $48(63)$ & $60(61)$ & $108(62)$ \\
\hline \multicolumn{4}{|l|}{ Had a planned programme for senior house } \\
\hline officer sessions & $41(54)$ & $61(62)$ & $102(58)$ \\
\hline Attended outpatients & $60(78)$ & $87(87)$ & $147(84)$ \\
\hline Attended child health clinics & $25(32)$ & $45(45)$ & $70(40)$ \\
\hline Attended handicap assessments centre & $23(30)$ & $32(32)$ & $55(31)$ \\
\hline Attended child psychiatry & $10(13)$ & $12(12)$ & $22(12)$ \\
\hline \multirow{2}{*}{$\begin{array}{l}\text { Mean percentage of time spent in general } \\
\text { paediatrics }\end{array}$} & & & \\
\hline & $65 \cdot 1$ & $70 \cdot 7$ & $68 \cdot 3$ \\
\hline
\end{tabular}

TABLE III-Experience in general practice component of vocational training as reported by first year principals in general practice

\begin{tabular}{lc}
\hline Experience in general practice while training & $\begin{array}{c}\text { No }(\%) \text { of } \\
\text { first year } \\
\text { principals } \\
(\mathrm{n}=139)\end{array}$ \\
\hline Teaching sessions on child health: & \\
$\quad$ Regular and planned & $26(19)$ \\
Ad hoc & $22(16)$ \\
None & $75(54)$ \\
No response & 16 \\
Child health clinics attended: & $32(23)$ \\
Over 10 & $16(11)$ \\
Six to 10 & $53(38)$ \\
\hline Fewer than six & $31(22)$ \\
None & 7 \\
No response & $24(17)$ \\
Attended school medical sessions & $92(66)$ \\
Received training in procedures for reporting child abuse & $27(19)$ \\
Attended course on developmental paediatrics & $89(64)$ \\
Sessions on paediatrics included in day release & \\
\hline
\end{tabular}

$(115 ; 83 \%)$ than among those on self constructed schemes $(64 ; 60 \%)(p=0 \cdot 01)$.

Table II gives details of the experience of the 175 doctors who had held a paediatric post in hospital. Only two had spent under a fifth of their time and over half had spent over three fifths of their time in general paediatrics.

For the 139 new principals (table III) the teaching in paediatrics that they had received during their general practice attachment ranged from regular planned sessions $(26 ; 19 \%)$ to no sessions $(75 ; 54 \%)$. For those who had had sessions, just under half were planned. Of the $101(73 \%)$ who attended child health clinics, $52(51 \%)$ carried out the paediatric assessments themselves and $22(22 \%)$ reported that they either observed or were instructed. Eighty nine of the new principals $(64 \%)$ reported that sessions in paediatrics were held on the day release scheme, but half had had fewer than five sessions. Thirty one new principals $(22 \%)$ had taken the examination for the diploma in child health.

The new principals were asked to say whether they thought that they had acquired 15 different skills in their training (table IV). The responses ranged from 37 (26\%) who thought that they could measure visual acuity at 3 years to $138(99 \%)$ who reported that they could run an immunisation programme. When the responses of those who had done a paediatric post were compared with the responses of those who had not there was a significantly higher self assessment over the whole list for the first group ( $p=0.05$, one tailed test for difference of means), and this was maintained for four separate skills (table IV).

\section{Discussion}

Doctors who complete vocational training without joining a three year scheme are less likely to have held a paediatric post in hospital, but overall in this study 175 (72\%) entrants into general practice had such experience. Trent region thus compares well with Britain as a whole, where only $58 \%$ of entrants in general practice in 1987 had experience in senior house officer posts in paediatrics. ${ }^{4}$ There is a limit to the number of available posts, and doctors who intend to enter general practice must compete with career paediatricians. But in this survey having completed a post in paediatrics appreciably affected the confidence that new principals had in their paediatric skills, which suggests that all vocational trainees should hold a post in paediatrics in hospital. The results also indirectly support the recommendation in the Court report that there should be general practitioners with special training in paediatrics who work exclusively with children.'

As an increase in the availability of senior house officer posts for vocational trainees is unlikely to occur 
No (\%) with experience as paediatric senior house officer

Skill

No $(\%)$ $(\mathbf{n}=99)$

Run a preschool surveillance programme

Run an immunisation programme

Follow procedures for cases of child abuse

Carry out new baby 6 week check

Test for hearing at 7 months

Measure visual acuity at 3 years

Look after an asthma attack in child aged 3 who has not responded to oral bronchodilators

Distinguish between innocent abnormal murmurs

Carry out Ortolani's and Barlow's tests

Manage a 3 year old with a urinary tract infection

Manage a baby of 6 weeks with vomiting

Manage a baby of 3 months with diarrhoea

Manage a febrile toddler with (query) meningitis

Support parents of a child with newly diagnosed Down's syndrome

Recognise exanthemas

${ }^{\star}$ Difference between those who had and had not had a senior house officer post is significant, $p=0 \cdot 05$.

in the short term it would be tempting to compensate for this by increasing the paediatric content of the general practice year of vocational training. But although general practice is a suitable place to hold short courses - for example, in developmental paediatrics-it is difficult to see how such training could effectively replace the experience gained from a full six month post in paediatrics.

If extra senior house officer posts in paediatrics were available the possibilities for teaching would be greater. Adapting some six month hospital posts in paediatrics to four months of hospital paediatrics and two months of community paediatrics would widen the training experience.

In the absence of such an initiative improvements can be made in two areas: firstly, in the extent to which paediatrics is taught in hospital and in general practice. Our results show that in a fifth of the senior house officer posts there was no regular teaching, and in only three fifths was there a planned educational programme. The shortfall appears to continue in the general practice attachment, where a fifth of the trainees did not attend child health clinics, and half of those who did carried out no developmental assessments personally.

The second improvement is remedial postgraduate training in paediatrics. In Scotland vocational trainees are offered a combination of academic modules in the school of community paediatrics at the University of Edinburgh and clinical work in the community. ${ }^{5}$ Also, courses might be offered for established principals in general practice. Such schemes can use modules from courses for the general professional training of career community paediatricians, as recommended by the Forfar report ${ }^{6}$ and as has occurred in Nottingham since 1984.

If the paediatric caseload is to be transferred to general practice, in particular routine child health surveillance, then our findings suggest that there is a requirement for both an increased amount of teaching for current trainees and remedial postgraduate training in paediatrics before the required skills can be assumed to be present. In the longer term more hospital posts in paediatrics will be needed for vocational trainees.

We thank the research staff of the British Paediatric Association for their help in data entry and analysis, in particular Linda Haines and Myer Glickman.

1 Committee on Child Health Services. Fit for the future. London: HMSO, 1976. (Court report.)

2 Royal College of General Practitioners Working Party. Healthier childrenthinking prevention. London: RCGP, 1982. (Report from general practice No 22.)

3 Department of Health and Social Security. Promoting better health. London: DHSS, 1987. (White paper.)

4 Styles W. Vocational training for general practice-hospital experience. London Joint Committee on Postgraduate Training for General Practice, 1988.

5 Farquhar J. A school of community paediatrics. Med Educ 1978;12:388-92.

6 Joint Working Party on the Training of Clinical Medical Officers in Child Health. Report. Br Med f 1982;284:637-40. (Forfar report.)

7 Polnay L, More EJ. General professional training in community child health. Arch Dis Child 1986;61:917-20.

(Accepted 16 March 1989)

\section{BOOKS RECEIVED}

\section{Epidemiology}

The Epidemiology and Prevention of Important Diseases. I D G Richards, Important Diseases. I D G Richards,
M R Baker. (Pp viii + 176; figs; $\$ 9.95$ M R Baker. (Pp viii +176; figs; $£ 9.95$
paperback.) Edinburgh: Churchill paperback.) Edinburgh: Churchill
Livingstone, 1988. ISBN 0-44302587-8.

\section{History of medicine}

Third HM Queen Elizabeth the Queen Mother Fellowship. "General Practice and Primary Health Care 1940s-1980s." J Fry. (Pp xii +115 £8.) London: Nuffield Provincial Hospitals Trust, 1988. ISBN 0-900574-69-0.

\section{Immunology}

Making Monoclonals: a Practical Beginners' Guide to the production and Characterization of Monoclonal Antibodies Against Bacteria and Viruses. bodies Against Bacteria and Viruses. DG Newell, B W McBride, $S$ A Clark.
(Pp iv +94 ; figs; $£ 10$ paperback. (Pp iv +94; figs; 10 paperback,
including postage.) Public Health including postage.) Public Health
Laboratory Service, 61 Colindale Laboratory Service, 61 Colindale
Avenue, London NW9 5DF. ISBN 0-901144-23-1.

Prostaglandins, Leukotrienes, and the Immune Response. J L Ninnemann. (Pp xii +220; figs; £25.) Cambridge: Cambridge University Press, 1988. ISBN 0-521-33483-7.

\section{Infection}

Anaerobic Infections: Clinical and Laboratory Practice. A T Willis, K D
Phillips. (Pp viii +169 ; figs; $£ 20$ paperback, including postage.) London: Public Health Laboratory Service, 1988. Available from PHLS Supplies,
61 Colindale Avenue, London NW9 SDF. ISBN 0-901144-22-3.

Infectious Disease and Therapy. Vol 1. "Parastic Infections in the Compromised Host." Ed P D Walzer, R M Neu. (Pp xvi+533; figs; \$150.) New Yeu. (Pp xvi+533; figs; \$150.) New 0-8247-7943-6.

Intensive care

Current Concepts in Critical Care. "Imaging and Labelling Techniques in the Critically Ill." Ed W Kox, Boultbee, R Donaldson. (Pp xv +188 figs and colour plates, 593 .) London: Springer, 1988. ISBN 3-540-17483-4. Pocket Reference Series. "Intensive Care." G R Park, A R Manara. (P xiii+299; figs; $£ 14.95$ paperback. Tunbridge Wells: Castle House, 1988. ISBN 0-7194-0120-8.

Medical education

400 More Self Assessment Picture Test in Clinical Medicine. Vol 2. Various authors. (Pp 264; figs and colour plates; £12.95 paperback.) London: Wolfe Medical, 1988. ISBN 0-7234 1516-1.

Medical ethics

Ethical Issues in Caring. Ed G and
$S$ Fairbairn. (Pp $x i+180 ; £ 22.50$.) Aldershot: Avebury, 1988. ISBN 0-566-05266-0.

Ethics and Aging: the Right to Live, the Right to Die. Ed J E Thornton, E R Winkler. (Pp xiii +256 ; $£ 13.55$ paperback.) Vancouver: University of back.) Vancouver: University of 0-7748-0310-X.

\section{Medicolegal}

New Reproductive Techniques: a Legal Perspective. D J Cusine. ( $\mathrm{Pp} \mathrm{x}+261$; Perspective. D J Cusine. (Pp x+261; 1988. ISBN 0-566-05410-8.

\section{Nephrology}

Contemporary Issues in Nephrology. Vol 18. "Immunopathology of Renal Disease." Ed C B Wilson. Series editors B M Brenner, J H Stein. (Pp vix +299; figs; £47.50.) New York: Churchill Livingstone, 1988. ISBN 0-443-08631-1.

\section{Neurology}

Medical Consultation Series. "Consultation in Neurology." L R Caplan, J J Kelly, Jr. Consulting editor J P Kassirer. (Pp viii + 388; figs; $£ 19.95$ paperback.) Toronto: Decker, 1988. Distributed by Blackwell Scientific. ISBN 1-55009-009-7.

Virus Infections and the Developing Nervous System. Ed R T Johnson, G Lyon. (Pp viii +162; figs; £35.) Dordrecht: Kluwer, 1988. ISBN 0-7462-0053-6.
Nutrition

Current Topics in Nutrition and Disease. Vol 20. "Pharmacology of Micronutrients." N W Flodin. Series editors nutrients." $N$ W Flodin. Series editors A A Albanese, D Kritchevsky. (P xil 340; figs; $\$ 69.50$.) New York: Liss, Sons. ISBN 0-8451-1619-3.

ILSI Human Nutrition Reviews. "Zinc in Human Biology." Ed C F Mills. Series editor I Macdonald. (Pp xix + 388; figs; f63.) London: Springer, 1989. ISBN 3-540-19529-7.

Nutritional Support of the Critically Ill. R Schlichtig, S M Ayres. (Pp xiv +223 ; figs; $£ 22.50$ paperback.) Chicago: Year Book Medical Publishers, 1988 Distributed by Wolfe Medical Publications. ISBN 0-8151-7655-4.

\section{Obstetrics and gynaecology}

Contemporary Issues in Obstetrics an Gynecology. Vol 3. "Obstetric Ultrasonography" and "Gynecologic Oncology." Ed R L Berkowitz, C J Cohen, N G Kase. Series editors N G Kase, R L Berkowitz. (Pp xiv +246 figs; £30.) New York: Churchill Livingstone, 1988. ISBN 0443 08601-X.

Endocrine Management of Infertility. Ed T J Wilkin. (Pp ix + 101; figs; $\$ 46$ paperback.) Chur, Switzerland: Harwood Academic, 1988. ISBN 3-7186-4827-X.

Implantation: Biological and Clinical Aspects. Ed M Chapman, G Grudzinskas, T Chard. (Pp xii + 258; figs; $£ 60$.)
London: Springer, 1988. ISBN 3-54019533-5.

Integrated Clinical Science. "Reproduction, Obstetrics and Gynaecology." Ed M G Elder. Series editor cology." Ed M G Elder. Series editor
G P McNicol. (Pp xiv + 333; figs; $£ 20$ G P McNicol. (Pp xiv + 333; figs; 220 paperback.) Oxford: Heinemann
Medical, 1988. ISBN 0-433-16609-6.

\section{Oncology}

Cancer Treatment and Research.

"Hodgkin's Disease in Children: Controversies and Current Practice." Ed W A Kamps, G B Humphrey, Poppema. (Pp xv+334; figs; £65.25.) Boston: Kluwer, 1989. Distributed by MTP Press. ISBN 0-89838-372-2.

Cancer Treatment and Research. "Malignant Melanoma: Biology, Malignant Melanoma: "Biology, Diagnosis, and Therapy." Ed L ( Series editor W L Miv 1928 ; figs; $£ 47.75$. Boston: Kluwer, 1988. Distributed by Medical Science Series. "Mathematica Models in Cancer Research." T E Wheldon. Series editor R F Mould. (Pp xvi + 247; figs; £37.50.) Bristol: Hilger, 1988. ISBN 0-85274-291-6.

Orthopaedics

Ellis Horwood Series in Biomechanical Engineering. "Engineering Theory in Orthopaedics: an Introduction." Ed M Green, L D M Nokes. (Pp 120; figs; £18.95.) Chichester: Ellis Horwood, 1988. Distributed by John Wiley and Sons. ISBN 0-7458-0337-7. 